\title{
Wives' Relative Income and Marital Quality in Urban China: The Role of Perceived Equity
}

\author{
Huiping Zhang $\cdot$ Sandra Kit Man Tsang
}

Published online: 18 September 2012

(C) The Author(s) 2012. This article is published with open access at Springerlink.com

\begin{abstract}
The debate over the association between wives' relative income (WRI) and marital quality remain controversial in the west; however, this important research area has been surprisingly under-studied against the backdrop of the fast socioeconomic transition in contemporary China. Using 763 urban Chinese wives, this study examined both the mediating and the moderating role of perceived equity between WRI and marital quality. Hierarchical multiple regression indicated that urban Chinese wives' relative income had a negative impact on their marital happiness and a positive impact on marital instability to a small extent. The mediating role of perceived equity was not supported in this study; however, perceived equity could buffer the positive effect of wives' relative income on marital instability, especially for higher-earning wives. This study contributes to understanding wives' socioeconomic resources and marital quality from an equity perspective in the Chinese context and generates implications for crosscultural research on perceived equity. It also serves for marital counseling on improving higher-earning wives' perception of fairness as well as family-friendly policy making.
\end{abstract}

Keywords Wives' relative income - Marital happiness - Marital instability · Perceived equity · Urban China

\section{Introduction}

The participation of married women in the labor market has been one of the most dramatic demographic changes to contemporary urban Chinese family (Edwige \&

\footnotetext{
H. Zhang $(\bowtie)$

Department of Social Work, The School of Sociology and Population Studies, Renmin University of China, No. 59, Zhongguancun Street, Haidian District, Beijing 100872, People's Republic of China e-mail: zhp0205@gmail.com
}

S. K. M. Tsang

Department of Social Work, The University of Hong Kong, Pokfulam Road, Hong Kong 
Jin, 2005). Urban married women economically contributing to the family have become the normative standard nowadays. Meanwhile, the crude divorce rate has increased significantly and steadily from about .3 to $1.8 \%$ over the period of 1979-2009 (State Statistical Bureau of China, 1980-2010). And it is speculated that China's divorce rate is likely to grow increasingly under the rapid socioeconomic transition (Wang, 2001; Wang \& Zhou, 2010). Is there a link between these two phenomenons?

The impact of women's income on marital outcomes has been studied intensively in the west, and the mainstream line of study supported the economic independence hypothesis (Parsons, 1949), i.e., wives' relative income (WRI) will lead to their marital dissatisfaction (Furdyna, Tucker, \& James, 2008) and it is positively associated with the risk of divorce (Heckert, Nowak, \& Snyder, 1998; Rogers \& Deboer, 2001; Kalmijn, Loeve, \& Manting, 2007). Equity theory argued that the negative impact of WRI on the wife's marital quality can be understood by her lowered perception of equity (Booth, Johnson, White, \& Edwards, 1984; Schafer \& Keith, 1981). Substantial evidence showed that wives do a much larger proportion of housework and childcare than their husbands even when they are employed fulltime outside home (Coltrane, 2000; Greenstein, 1996); thus, decreasing the wife's perceived equity due to unequal division of paid and housework roles between spouse.

Some studies indicated that Asian couples put the priority on the interests of groups rather than individuals, i.e., they tend to be more concerned about maximizing joint outcomes of the family rather than dividing the outcomes between the individual partners (Choi \& Keith, 1991; Park \& Cho, 1995), so the perception of equity may have less importance for Asian married people. However, China has undergone fast social and cultural changes through the modernization process and open-door policy during the reform era, and it is reasonable to expect some changes in the equity orientations within Chinese marriages.

Compared with the rich knowledge in the west, studies of the impact of WRI on marital quality during the fast socioeconomic change period in urban China are surprisingly scarce. It is high time that this important area be understood intensively, therefore, the purpose of this study is to examine the impact of urban Chinese WRI on their marital quality, and also examine the role of perceived equity in this association.

\section{Resource Exchange Theory}

An early attempt to talk about the link between WRI and marital quality was the resource exchange theory (Homans, 1961; Thibaut \& Kelley, 1959), which argued that in relationships people try to maximize self-interest through exchanging resources. Resources are anything of value, tangible or intangible, that couples bring to their relationship (Blood \& Wolfe, 1965). They include money, occupational or social status, education, love and affection, physical attractiveness, special knowledge or expertise, services (such as performing domestic labor), and so on. In the traditional marriage (e.g., male breadwinner-female homemaker family 
model), men contribute their incomes, as well as the status associated with their occupations, in exchange for women's domestic labor and childcare services.

This theory has been supported by many economists (Becker, 1981; Parsons, 1949), who contend that gender-based task specialization within marriage provides the most efficient system of exchange. The husband and the wife within such families have complementary and specialized functions. Historically, men occupied a better position in the labor market, so couples relying on earning capacity will maximize their economic rewards, while a woman's contribution is maximized through their dedication to domestic work and children care. Based on this economic function and exchange approach, couples who do not follow this gender-based specialization model would be at a disadvantage in both the economic and the domestic spheres, which may lead to lower marital satisfaction (Furdyna et al., 2008). The stability of marriage would be threatened if the wives earned more than their husbands or had higher occupational prestige (Parsons, 1949). Therefore, based on the argument by resource exchange theory, the following hypothesis is proposed in this study:

Hypothesis set 1 Wives' relative income will be associated with their marital happiness negatively and associated with marital instability positively.

\section{Equity-Oriented Resource Exchange Theory}

Substantial evidence has shown that the social exchange process follows the relational justice principles (Sabatelli, 1999), which refers to a fair distribution of rewards (outcomes) and costs (investments) among the partners. In other words, each person's return is commensurate with his or her investment. When people feel overbenefited in the social exchange relationship, they are likely to report guilt and shame, while the under-benefited may experience anger, sadness, and resentment (Hatfield, Rapson, \& Aumer-Ryan, 2008; Walster, Hatfield, Walster, \& Berscheid, 1978). Many scholars have applied the principles of equity theory into marital relationships (Demaris, 2007, 2010; Frisco \& Williams, 2003) as well as romantic relationships (Demaris \& Longmore, 1996; VanYperen \& Buunk, 1991). Based on the equity theory, the bargain that in traditional marital arrangements husbands exchange their income for the domestic labor and child care that wives provide is fair to each spouse in the marital relationship and they are "doing gender" as expected according to their established social and cultural values (West \& Zimmerman, 1987). A review of the literature indicates that there are three possible ways in which perceived equity influences marital quality as elaborated in the following sections:

\section{Direct Effect}

Previous studies showed that individuals in inequitable relationships reported less satisfaction than others (Buunk \& Mutsaers, 1999; Buunk \& Van Yperen, 1991; VanYperen \& Buunk, 1991) and they were more likely to report marital dissolution (DeMaris, 2007; Frisco \& Williams, 2003). Mikula (1998) also found that marital quality was related to perceived fairness in household labor, and perceived fairness 
was more important in this relationship than the actual division of chores. Similarly, Coltrane (2000) showed that perceived fairness in the division of household labor was associated with marital quality, especially for women. Moreover, perceived fairness of division of labor was found to be related with conflict to the greatest degree among middle class women (Perry-Jenkins \& Folk, 1994) and Voydanoff and Donnelly (1999) also indicated that women's perceived unfairness of housework negatively influenced the relationship between actual time doing chores and marital disagreement. So, the following hypothesis was proposed:

Hypothesis set 2 Wives' perceived equity is positively associated with marital happiness and negatively associated with marital instability.

\section{Mediating Effect}

The most widely studied aspect of perceived equity as a mediator is focused on equity on division of housework. The wives' increasing income may lead to conflict, given that wives with more income expect more equity in house work (Booth et al., 1984; Schwartz, 1989). Previous studies have argued that the increase in husbands' contributions to household labor does not necessarily mean that wives have received real relief or help from their husbands' participation in domestic activity (Coltrane, 2000; Bianchi, Milkie, Sayer, \& Robinson, 2000; Whyte, 1990). For example, crosscountry studies showed that as women's labor force participation continues to increase, the increase in the men's share of domestic work and childcare remain at about one-third of the time contribution of women (Blossfeld \& Drobni, 2001; Gershuny, 2003). So, perception of equity over domestic labor and other family issues has become increasingly salient for contemporary marriages (Rogers \& Amato, 2000) and this possibility is especially likely when viewed within the context of an increase in wives' employment. Yang (2004) surveyed 107 young middle-class couples in Korea and found that the effects of a wife's employment on her own and husband's marital quality were both mediated through the wife's perceived equity. In addition, several studies also showed that perceived fairness mediates the relationship between division of labor and marital quality (Lavee \& Katz, 2002; Wilkie, Ferree, \& Ratcliff, 1998). Considering that WRI is associated with wives' perceived equity and perceived equity is associated with marital quality, a number of studies have considered the perception of equity to be a mediating variable between WRI and marital quality (see a review of Coltrane, 2000). So, the following mediating hypothesis was proposed:

Hypothesis set 3 Perceived equity mediates the association between wives' relative income and marital happiness (instability); i.e., when wives' relative income increases, perceived equity will decrease, which in turn will reduce (increase) marital happiness (instability).

\section{Moderating Effect}

In contrast with the substantial evidence for the mediating role of perceived equity, some studies also showed the possible moderating role of perceived equity. For 
example, an in-depth interview of 39 married couples in Beijing indicated that the unequal distribution of housework did not lead to perceived inequity for employed women (Zuo \& Bian, 2001). Tichenor (2005) interviewed 22 couples where the wife's income was higher and found that the majority of wives continue to perform the bulk of household chores and childcare, exert little control over money, and enjoy limited decision-making power, despite their substantial incomes. To be specific, some higher-earning wives may feel the marriage is not fair because spouses are not contributing to their relationships as expected, which makes it difficult for them to recognize the values of the couples' contributions, thus disrupting the balance of exchange. But there are also some higher-earning wives who feel the relationship is fair, because they really get more relief from domestic labor than employed wives generally do. In this sense, WRI is not necessarily related to perceived equity, so perceived equity may also work as a moderator in the association between WRI and marital quality. So, the following moderating hypothesis was proposed:

Hypothesis set 4 Perceived equity moderates the association between wives' relative income and marital happiness (instability); i.e., there is a stronger negative relationship between wives' relative income and marital happiness (instability) for perceived lower equity wives than for perceived higher equity wives.

\section{Method}

Data

Based on the research purpose, 798 urban married women were recruited by a purposive and convenient sampling method through three classes in one primary school in Beijing in February 2010. 35 questionnaires were deleted due to incomplete information regarding WRI, being second marriages, or that over half of these questionnaires were blank. The final urban sample was 763 wives with a mean age of 38.58 years $(S D=3.23)$ and a marital duration of 13.10 years $(S D=2.76)$. $55.3 \%$ of them obtained university or graduate degrees, $32.9 \%$ has received secondary education or vocational training, and $11.7 \%$ of them only received primary or below education. All of them were in their first marriage and $62.4 \%$ reported that they lived in a nuclear family. Nearly $90 \%$ of the participants were permanent residents of Beijing. The response rate was $79.8 \%$.

Measures

\section{Marital Quality}

Fincham and Linfield (1997) conceptualized and measured marital quality as two separate dimensions, comprising positive marital quality (PMQ) and negative marital quality (NMQ). In this study, the positive and negative dimensions of marital quality were measured with marital happiness subscale and marital instability subscale, respectively. Marital Happiness was measured with a 15-item 
scale tapping the respondents' happiness with a range of aspects of the marriage (see Johnson, White, Edeards, \& Booth, 1986). For example, respondents were asked how happy they were with the amount of understanding they received from their spouse, the amount of love and affection they received from their spouse, the extent to which they and their spouse agreed about things, and their sexual relationship. Responses were rated on a 4-point Likert scale $(1=$ "very unhappy", 2 = "unhappy", $3=$ "happy", and 4 = "very happy"). An index variable is computed with higher scores indicating a more happy marriage. The reliability of marital happiness in this study is .94 .

For the Marital Instability subscale, participants were asked about the frequency of the five statements occurring in their marriage: (1) have you or your husband ever seriously suggested the idea of divorce; (2) have you discussed the divorce or separation with close friends; (3) have you ever thought your marriage might be in trouble; (4) has the thought of getting a divorce or separation crossed your mind in the past 3 years; (5) have you separated with your spouse. Responses were rated on a 4-point Likert scale ( 1 = "never", 2 = "long time ago", $3=$ "three years ago", and $4=$ "recently"). An index variable is computed with higher scores indicating more marital instability. The reliability of marital instability in this study is .86.

WRI refers to the wife's relative contribution to total family income. It is computed using the wife's annual income divided by the sum of both husband and wife's annual income. To be consistent with previous studies (Nock, 2001; Rogers, 2004; Teachman, 2010), WRI was constructed as a categorical variable and three groups of wives were defined as: (1) lower-earning wives (0-39\%); (2) equalearning wives (40-59 \%); and (3) higher-earning wives (60-100\%).

The Marital Perceived Equity Scale (MPES, Sexton \& Perlman, 1989). This scale is used to assess perceived equity in marital relationships in the areas of finances, housekeeping, care and socialization of children, recreation, understanding, and kinship relations. The items were rated on a 7-point Likert scale ranging from "I get a much better deal than my spouse" (1) to "my spouse gets a much better deal than me" (7). There are two competing theories regarding the nature of the relationship between perceived equity and marital quality. Social exchange theory assumes a linear relationship between relative benefit and marital quality, and equity theory predicts a curvilinear relationship between them (Sprecher \& Schwartz, 1994). Specifically, social exchange theory argues that over-benefited individuals will have the highest marital happiness and under-benefited will have the lowest marital happiness. While, equity theory assumes that both over- and under-benefited individuals will be less satisfied with marital happiness than equitably treated individuals. To examine which perspective is more valid for Chinese married women, preliminary analyses were performed using two different coding systems. One is the original coding (coded as $1-7$, where 7 indicates highest level of relative benefit), which follows the social exchange perspective, and another coding is in line with equity theory (Perry, 2004). these Likert points were recoded as follows: 1 = "I get a much better deal than my spouse", $2=$ "My spouse gets a much better deal than me", 3 = "I get a somewhat better deal than my spouse", 4 = "My spouse gets a somewhat better deal than me", $5=$ "I get a slightly better deal than my spouse", $6=$ "My spouse gets a slightly better deal than me", and 
$7=$ "I get an equal deal with my spouse". The correlations between equity and marital happiness and instability were compared based on these two systems and the second one indicates higher correlations $\left(r_{1}=.28, r_{2}=-.23\right)$, so the second coding is adopted in this study. The marital perceived equity index was computed with higher scores indicating higher perceived equity. The reliability of marital perceived equity in this study is .77 .

\section{Statistical Analysis}

The analysis was performed in three parts using SPSS 16.0 software (Chicago, IL: SPSS Inc.). First, Chi-squared and ANOVA tests were run to examine the profiles and differences of marital quality among three groups of wives. Second, the mediating effect was examined through the procedures as suggested by Baron and Kenny (1986). However, based on our preliminary analysis, WRI is not significantly correlated with marital quality at the .01 level, and WRI is associated with marital quality to a very minor extent (with partial $\eta^{2}<.02$ ), so the mediating effect of perceived equity could not be examined. In other words, the hypothesized mediating role of perceived equity could not be supported in this study. Third, the moderating effect was tested by hierarchical multiple regression equations (Baron \& Kenny 1986; Frazier, Tix, \& Barron, 2004): (1) regressing the outcome variable on the predictor; (2) regressing the outcome variable on the moderator; and (3) regressing the product terms of the predictor and the moderator. The moderator hypothesis is supported if the interaction is significant. There may also be significant main effects for the predictor and the moderators, but these are not conceptually directly relevant to testing the moderator hypothesis. Once a significant moderating effect was identified, simple slope tests were performed to further interpret the interaction effects. Following the procedures outlined by (Aiken, West, \& Reno, 1991), separate regression lines were computed, plotted, and tested for individuals who were one standard deviation below the mean on the moderator, and one standard deviation above the mean of the moderator.

\section{Results}

Table 1 presents the profiles of urban Chinese wives: lower-earning wives consisted of around $50 \%$, equal-earning wives consisted of $43 \%$, and higher-earning wives consisted of around $7 \%$. The $\chi^{2}$ and ANOVA test results suggested that these three groups of wives showed similar characteristics on both demographic and socioeconomic factors $(p>.05)$, which satisfied the requirements for the direct comparison among the three groups of wives.

Further analyses in Table 2 indicated that the significant main effect of relative income was found to be on marital happiness, $F(2,746)=5.88, p<.01$, and marital instability $F(2,746)=5.62, p<.01$. In general, higher-earning wives reported lower marital happiness and higher marital instability than lower- and equal-earning wives. There is no difference on marital happiness and marital instability between lower- and equal-earning wives. 
Table 1 Characteristics of three groups of wives in the urban samples $(N=763)$

\begin{tabular}{lllll}
\hline & $\begin{array}{l}\text { Lower-earning } \\
(n=374)\end{array}$ & $\begin{array}{l}\text { Equal-earning } \\
(n=336)\end{array}$ & $\begin{array}{l}\text { Higher-earning } \\
(n=53)\end{array}$ & Test statistics \\
\hline Age M $(S D)$ & $38.30(2.93)$ & $38.79(3.55)$ & $39.30(3.23)$ & $F=3.44$ \\
Years of marriage M $(S D)$ & $12.92(2.46)$ & $13.32(3.09)$ & $12.96(2.56)$ & $F=1.83$ \\
Education (\%) & & & & $\chi^{2}=9.40$ \\
Primary or below & 11.8 & 12.6 & 5.8 & \\
Secondary & 37.4 & 27.9 & 32.7 & \\
College or above & 50.8 & 59.5 & 61.5 & \\
Family annual income $(\%)$ & & & & \\
$\leq 44,000$ RMB & 14.1 & 12.3 & 12.0 & \\
44,001-80,000 RMB & 28.3 & 26.7 & 30.0 & \\
80,001-115,000 RMB & 19.1 & 19.6 & 16.0 & \\
115,001-150,000 RMB & 16.1 & 17.5 & 10.0 & \\
150,001-185,000 RMB & 7.2 & 9.2 & 8.0 & \\
$>185,000$ RMB & 15.2 & 14.7 & 24.0 & \\
\hline
\end{tabular}

Table 2 Marital quality by wives' relative income

\begin{tabular}{lccccc}
\hline & $\begin{array}{l}\text { Lower-earning } \\
M(S D)\end{array}$ & $\begin{array}{l}\text { Equal-earning } \\
M(S D)\end{array}$ & $\begin{array}{l}\text { Higher-earning } \\
M(S D)\end{array}$ & $F$ & Post hoc \\
\hline Marital Happiness & $35.96(.45)$ & $35.69(.43)$ & $32.63(.88)$ & $5.88^{* *}$ & L, E $>$ H \\
Marital Instability & $7.21(.26)$ & $6.90(.25)$ & $8.81(.51)$ & $5.62^{* *}$ & L, E $<$ H \\
\hline
\end{tabular}

$L$ lower-earning wives, $E$ equal-earning wives, $H$ higher-earning wives

** $p<.01$

Table 3 Zero-order correlations between marital perceived equity, marital happiness and marital instability

\begin{tabular}{lccc}
\hline & $\begin{array}{l}\text { Marital perceived } \\
\text { equity }\end{array}$ & $\begin{array}{l}\text { Marital } \\
\text { happiness }\end{array}$ & $\begin{array}{l}\text { Marital } \\
\text { instability }\end{array}$ \\
\hline Marital perceived equity & 1.00 & & \\
Marital happiness & $.28^{* *}$ & 1.00 & 1.00 \\
Marital instability & $-.23^{* *}$ & $-.58^{* *}$ & 1.00 \\
\hline
\end{tabular}

$* * p<.01$

Based on the zero-order correlation analyses in Table 3, the direct association of marital perceived equity was found with respect to urban women's marital happiness $(r=.28, p<.01)$ as well as marital instability $(r=-.23, p<.01)$. To examine the moderating effect of marital perceived equity, the predictor of WRI as a categorical variable with three levels was dummy coded as two variables: WRI2 (equal-earning) and WRI3 (higher-earning). Marital perceived equity and two dimensions of marital quality were standardized before the regression. And two 
Table 4 The moderating effect of marital perceived equity on marital happiness and marital instability

$\begin{array}{lllll}B & S E & \beta & \Delta F & \Delta R^{2}\end{array}$

\begin{tabular}{|c|c|c|c|c|c|}
\hline \multicolumn{6}{|c|}{ Marital Happiness } \\
\hline Block one & & & & $8.71 * * *$ & .02 \\
\hline WRI2 & -.78 & .41 & -.07 & & \\
\hline WRI3 & -3.23 & .79 & $-.15 * * *$ & & \\
\hline Block two & & & & $66.12 * * *$ & .08 \\
\hline MPE & 1.33 & .27 & $.24 * * *$ & & \\
\hline Block three & & & & 2.12 & .005 \\
\hline WRI $2 \times$ MPE & .24 & .40 & .03 & & \\
\hline WRI3 $\times$ MPE & 1.47 & .71 & $.08 *$ & & \\
\hline Total $R^{2}$ & & & & & .11 \\
\hline Adjusted $R^{2}$ & & & & & .10 \\
\hline \multicolumn{6}{|c|}{ Marital Instability } \\
\hline Block one & & & & $5.90 * *$ & .01 \\
\hline WRI2 & .09 & .23 & .01 & & \\
\hline WRI3 & 1.34 & .46 & $.11 * *$ & & \\
\hline Block two & & & & $43.15^{* * * *}$ & .05 \\
\hline MPE & -.59 & .16 & $-.19 * * *$ & & \\
\hline Block three & & & & $4.29 *$ & .01 \\
\hline WRI $2 \times$ MPE & -.08 & .23 & -.02 & & \\
\hline WRI3 $\times$ MPE & -1.20 & .41 & $-.11^{* *}$ & & \\
\hline Total $R^{2}$ & & & & & .08 \\
\hline Adjusted $R^{2}$ & & & & & .07 \\
\hline
\end{tabular}

After controlling for the age, education, and family income, the results remain nearly the same, so these factors are not shown in the table

Beta coefficients are standardized

WRI2 equal-earning wives, WRI3 higher-earning wives, MPE marital perceived equity

$* p<.05, * * p<.01, * * * p<.001$

interaction terms were created, including WRI $2 \times$ MPE, WRI3 $\times$ MPE. As can be seen from Table 4 , the moderating effect of perceived equity was only found in the association between WRI and marital instability $\left(F=4.29, p<.05, \Delta R^{2}=.01\right)$. Separate correlations between WRI and marital instability were examined for urban wives who were one standard deviation above the mean of marital perceived equity (high MPE), and one standard deviation below the mean of marital perceived equity (low MPE). The differentiated correlations for the three groups are further shown in Fig. 1. For higher-earning wives perceiving low marital equity, higher marital instability were reported $\left(B_{2}=.47 \pm .88, t=.53, p>.05 ; B_{3}=3.34 \pm 1.28\right.$, $t=2.62, p<.05$ ); while for higher-earning wives with high perceived equity, WRI was unrelated to marital instability $\left(B_{2}=-.32 \pm .45, t=-.70, p>.05\right.$; $\left.B_{3}=.36 \pm .92, t=.39, p>.05\right)$. 
Fig. 1 The moderating effect of marital perceived equity between wives' relative income and marital instability

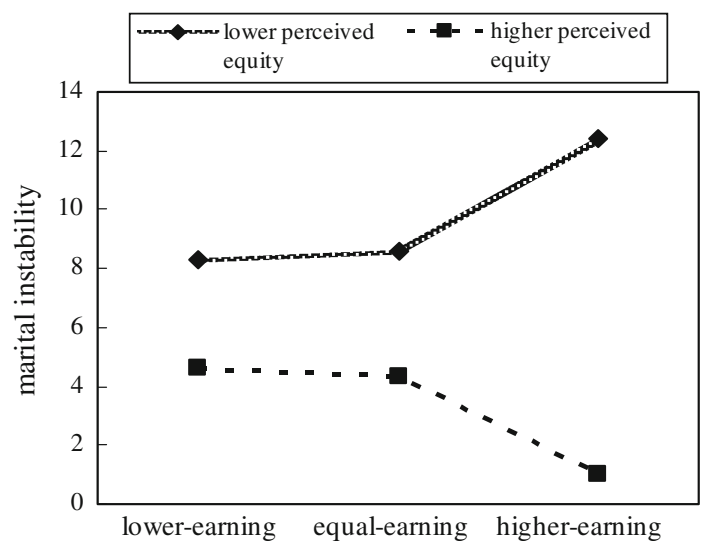

\section{Discussions}

We hypothesized that WRI has a negative association with their marital happiness and a positive association with marital instability. This hypothesis was supported in urban Chinese sample. However, the contribution of relative income to marital quality and instability were very small, ranging from 1 to $2 \%$. Gong (2007) found that relative income is not associated with any dimension of marital quality for either husbands or wives, based on three American longitudinal datasets over the period of time from 1980 to 1996. Furthermore, Winslow-Bowe (2007) showed that wives' income advantage does not affect marital conflict as long as it is persistent in 4 or 5 years out of five.

Our interpretation for the small contribution of WRI to marital quality was that the changing family demography and gender norms regarding married women's employment may contribute to the low impact of WRI on marital quality (Wilkie et al., 1998). For example, in the 1960s, American women's employment exerted a negative influence on marital quality, particularly for their husbands (Orden \& Bradburn, 1969). By the 1970s, studies found that there was no difference in marital quality for husbands and wives in dual-earner families and families in which the husband was the only wage earner (Glenn \& Weaver, 1978; Locksley, 1980). However, from the 1980s to the present, evidence began to emerge showing that when wives have full-time employment there is a positive impact on marital quality (Schoen, Rogers, \& Amato, 2006; Simpson \& England, 1981). Similarly, it has been a standardized life for urban Chinese married women to make economic contribution to the family, especially for prime aged families (Parish \& Farrer, 2000). Given the stability and recognition of wives' employment in the broader Chinese context over the past three decades, the impact of WRI may not be so severe.

The second hypothesis of the direct association of perceived equity with marital happiness and instability has been fully supported in urban Chinese women sample. The above findings are in line with American studies that demonstrate a positive relationship between perceived equity and marital happiness (Blair, 1993, 1998; Frisco \& Williams, 2003; Wilcox \& Nock, 2006).Compared with the study on 
Korean couples, the correlation between perceived equity and marital satisfaction in this study was lower than that in Yang's (2004) study $(r=.49, p<.01)$.

The third hypothesis that perceived equity mediates the relationship between WRI and marital quality was not supported. The association between WRI and marital perceived equity was not statistically significant, which is consistent with the previous findings on Chinese couples (Zuo \& Jiang, 2009), so the requirements for this study to examine the mediating effect of perceived equity totally failed.

Finally, our findings provide empirical evidence for the hypothesis that higherearning urban wives perceiving lower equity reported higher marital instability than those perceiving higher equity, which confirmed the moderating effect of perceived equity on higher-earning wives' marital instability. We can infer from this finding that, when wives earn more than their husband, if they still regard other aspects of family life as being fair, such an income arrangement does not exert a negative impact on wives' risk of divorce. However, no significant moderating effect of perceived equity was observed on marital happiness. This finding may be interpreted as marital happiness was not sensitive indicators of marital quality when the wife earns more than her husband.

However, is it possible for higher-earning wives to feel that their marriage is fair in real life? One possibility is for their husbands to hold an egalitarian gender ideology and then the wives could get some relief from domestic labor. Previous studies showed that egalitarian husbands tend to do more housework, whereas traditional husbands who are unemployed or severely underemployed often refuse to perform domestic labor, to assert their masculine identity and privilege (Bittman, England, Sayer, Folbre, \& Matheson, 2003; Greenstein, 2000).

This study informs our understanding of wives' resources and marital quality in several ways: first, this is the first attempt to explore this important but understudied research area in mainland China. The study on the impact of wives' socioeconomic status is mainly focused on marital power (Shu, 2005; Zuo \& Bian, 2001, 2005), but its impact on marital quality has not been paid enough attention to.

Second, this study has contributed to the verification of equity theory in urban China, which provides a useful angle to understand the relationship between wives' socioeconomic resources and marital quality and generates implications for crosscultural research on the role of perceived equity in marital quality. It seems not so difficult for Chinese married people to evaluate perceived fairness in different areas, which is contrary to the priority of family interests emphasized by married couples in traditional Chinese culture (Levy, 1968). So, perceived equity does matter in contemporary Chinese marriage.

Third, this study has important implications for marital counseling. Counselors should help higher-earning wives gain a perceived fairness through increasing their husbands' behavior and efforts in the area of domestic labor, childcare, and other family activities; or to help higher-earning wives restore the perceived fairness through psychological intervention.

Finally, this study serves for a policy-making purpose. Dual-worker family has become the norm among contemporary Chinese marriage (Parish \& Farrer, 2000). Gone are the days in which employers could assume that their employees had someone at home to manage all the tasks involved in life away from work. Not only 
are women increasingly employed outside the home but also a growing minority earn roughly as much as or more than their husbands in any given year (WinslowBowe, 2009). It will be much better for organizations to develop some friendly work-family balance policies.

\section{Limitations of This Study}

Although this study has contributed a lot to investigate this interesting topic in the fast-changing socioeconomic context of China, the limitations and directions for further study should be noted:

First, the persistence of the wives' income advantage is unclear because of the cross-sectional data; therefore, the impact of WRI fluctuation on marital quality cannot be obtained from this study.

Second, the samples in this study are not representative of the urban Beijing population in certain aspects: the wives were approached through a school-base, so those wives without children or whose children drop out of school have been excluded. The husbands were also not included in the main study, which simplified the examination of the marital relationship to some extent.

Third, differences in sample sizes of the three groups has limited the explanation power (Frazier et al., 2004). Though the samples of lower- and equal-earning groups were both sufficiently large enough to examine the differences in targeted variables, the relatively small sample size of higher-earning wives limited the advanced statistical analysis.

Acknowledgments This research was supported by the National Social Sciences Fund of China (12CSH035).

Open Access This article is distributed under the terms of the Creative Commons Attribution License which permits any use, distribution, and reproduction in any medium, provided the original author(s) and the source are credited.

\section{References}

Aiken, L., West, S., \& Reno, R. (1991). Multiple regression: Testing and interpreting interactions. Newbury Park, CA: SAGE.

Baron, R., \& Kenny, D. (1986). The moderator-mediator variable distinction in social psychological research: Conceptual, strategic, and statistical considerations. Journal of Personality and Social Psychology, 51(6), 1173-1182.

Becker, G. S. (1981). A treatise on the family. Cambridge: Harvard University Press.

Bianchi, S., Milkie, M., Sayer, L., \& Robinson, J. (2000). Is anyone doing the housework-trends in the gender division of household labor. Social Force, 79, 191.

Bittman, M., England, P., Sayer, L., Folbre, N., \& Matheson, G. (2003). When does gender trump money? Bargaining and time in household work. American Journal of Sociology, 109(1), 186-214.

Blair, S. (1993). Employment, family, and perceptions of marital quality among husbands and wives. Journal of Family Issues, 14(2), 189.

Blair, S. (1998). Work roles, domestic roles, and marital quality: Perceptions of fairness among dualearner couples. Social Justice Research, 11(3), 313-335. 
Blood, R. O., \& Wolfe, D. M. (1965). Husbands \& wives: The dynamics of married living. New York: Free Press.

Blossfeld, H., \& Drobni, S. (2001). Careers of couples in contemporary societies: from male breadwinner to dual-earner families. Oxford: Oxford University Press.

Booth, A., Johnson, D., White, L., \& Edwards, J. (1984). Women, outside employment, and marital instability. American Journal of Sociology, 90(3), 567-583.

Buunk, B., \& Mutsaers, W. (1999). Equity perceptions and marital satisfaction in former and current marriage: A study among the remarried. Journal of Social and Personal Relationships, 16(1), 123.

Buunk, B., \& Van Yperen, N. (1991). Referential comparisons, relational comparisons, and exchange orientation: Their relation to marital satisfaction. Personality and Social Psychology Bulletin, 17(6), 709-717.

Choi, S., \& Keith, P. M. (1991). Are "worlds of pain" cross-cultural? Korean working class marriages. Journal of Comparative Family Studies, 22(3), 293-312.

Coltrane, S. (2000). Research on household labor: Modeling and measuring the social embeddedness of routine family work. Journal of Marriage and the Family, 62, 1208-1233.

DeMaris, A. (2007). The role of relationship inequity in marital disruption. Journal of Social and Personal Relationships, 24(2), 177.

DeMaris, A. (2010). The 20-year trajectory of marital quality in enduring marriages: Does equity matter? Journal of Social and Personal Relationships, 27(4), 449.

DeMaris, A., \& Longmore, M. (1996). Ideology, power, and equity: Testing competing explanations for the perception of fairness in household labor. Social Forces, 74, 1043-1071.

Edwige, K., \& Jin, X. R. (2005). Labour force participation of married women in China and Congo. Journal of Zhejiang University-Science A, 6(4), 350-354.

Fincham, F., \& Linfield, K. (1997). A new look at marital quality: Can spouses feel positive and negative about their marriage? Journal of Family Psychology, 11(4), 489-502.

Frazier, P., Tix, A., \& Barron, K. (2004). Testing moderator and mediator effects in counseling psychology research. Journal of Counseling Psychology, 51(1), 115-134.

Frisco, M., \& Williams, K. (2003). Perceived housework equity, marital happiness, and divorce in dualearner households. Journal of Family Issues, 24(1), 51.

Furdyna, H. E., Tucker, M. B., \& James, A. D. (2008). Relative spousal earnings and marital happiness among African American and white women. Journal of Marriage \& Family, 70(2), 332-344.

Gershuny, J. (2003). Changing times: Work and leisure in postindustrial society. New York: Oxford University Press Inc.

Glenn, N., \& Weaver, C. (1978). A multivariate, multisurvey study of marital happiness. Journal of Marriage and the Family, 40(2), 269-282.

Gong, M. (2007). Does status inconsistency matter for marital quality? Journal of Family Issues, 28(12), 1582.

Greenstein, T. (1996). Gender ideology and perceptions of the fairness of the division of household labor: Effects on marital quality. Social Forces, 74, 1029-1042.

Greenstein, T. (2000). Economic dependence, gender, and the division of labor in the home: A replication and extension. Journal of Marriage and Family, 62(2), 322-335.

Hatfield, E., Rapson, R., \& Aumer-Ryan, K. (2008). Social justice in love relationships: Recent developments. Social Justice Research, 21(4), 413-431.

Heckert, D., Nowak, T., \& Snyder, K. (1998). The impact of husbands' and wives' relative earnings on marital disruption. Journal of Marriage and the Family, 60, 690-703.

Homans, G. (1961). Social behavior: Its elementary forms. New York: Harcourt, Brace and World.

Johnson, D. R., White, L. K., Edeards, J. N., \& Booth, A. (1986). Dimensions of marital quality: Toward methodological and conceptual refinement. Journal of Family Issues, 7(1), 31-49.

Kalmijn, M., Loeve, A., \& Manting, D. (2007). Income dynamics in couples and the dissolution of marriage and cohabitation. Demography, 44(1), 159-179.

Lavee, Y., \& Katz, R. (2002). Division of labor, perceived fairness, and marital quality: The effect of gender ideology. Journal of Marriage \& Family, 64(1), 27-39.

Levy, M. (1968). The family revolution in modern China. Cambridge: Harvard University Press.

Locksley, A. (1980). On the effects of wives' employment on marital adjustment and companionship. Journal of Marriage \& Family, 42(2), 337-346.

Mikula, G. (1998). Division of household labor and perceived justice: A growing field of research. Social Justice Research, 11, 215-241.

Nock, S. (2001). The marriages of equally dependent spouses. Journal of Family Issues, 22(6), 755-775. 
Orden, S., \& Bradburn, N. (1969). Working wives and marital happiness. American Journal of Sociology, 74(4), 392-407.

Parish, W. L., \& Farrer, J. (2000). Gender and family. In W. F. Tang \& W. L. Parish (Eds.), Chinese urban life under reform: The changing social contract (pp. 232-272). Cambridge: Cambridge University Press.

Park, I. H., \& Cho, L. (1995). Confucianism and the Korean family. Journal of Comparative Family Studies, 26(1), 117-134.

Parsons, T. (1949). The social structure of the family. In R. Anshen (Ed.), The family: Its function and destiny (pp. 173-201). New York: Harper \& Brothers.

Perry, B. J. (2004). The relationship between equity and marital quality among Hispanics, African Americans and Caucasians. Unpublished doctoral dissertation, The Ohio State University, United States.

Perry-Jenkins, M., \& Folk, K. (1994). Class, couples, and conflict: Effects of the division of labor on assessments of marriage in dual-earner families. Journal of Marriage and the Family, 56(1), $165-180$.

Rogers, S. (2004). Dollars, dependency, and divorce: Four perspectives on the role of wives' income. Journal of Marriage and Family, 66(1), 59-74.

Rogers, S., \& Amato, P. (2000). Have changes in gender relations affected marital quality? Social Forces, 79, 731-753.

Rogers, S., \& DeBoer, D. (2001). Changes in wives' income: Effects on marital happiness, psychological well-being, and the risk of divorce. Journal of Marriage and the Family, 63, 458-472.

Sabatelli, R. M. (1999). Marital commitment and family life transitions: A social exchange perspective on the construction and deconstruction of intimate relationships. In J. M. Adams \& W. H. Jones (Eds.), Handbook of interpersonal commitment and relationship stability (pp. 181-192). New York: Kluwer Academic/Plenum Publishers.

Schafer, R. B., \& Keith, P. M. (1981). Equity in marital roles across the family life cycle. Journal of Marriage and the Family, 43, 359-367.

Schoen, R., Rogers, S., \& Amato, P. (2006). Wives' employment and spouses' marital happiness: Assessing the direction of influence using longitudinal couple data. Journal of Family Issues, 27(4), 506.

Schwartz, F. (1989). Management women and the new facts of life. Harvard Business Review, 67(1), $65-76$.

Sexton, C., \& Perlman, D. (1989). Couples' career orientation, gender role orientation, and perceived equity as determinants of marital power. Journal of Marriage and the Family, 51(4), 933-941.

Shu, X. (2005). Market transition and gender segregation in urban China. Social Science Quarterly, 86(s1), 1299-1323.

Simpson, I. H., \& England, P. (1981). Conjugal work roles and marital solidarity. Journal of Family Issues, 2(2), 180-204.

Sprecher, S., \& Schwartz, P. (1994). Equity and balance in the exchange of contributions in close relationships. In M. J. Lerner \& G. Mikula (Eds.), Entitlement and the affectional bond: Justice in close relationships (pp. 325-340). New York: Plenum Press.

State Statistical Bureau of China. (2010). China Statistical Yearbook at various years. Beijing: China Statistical Press.

Teachman, J. (2010). Wives' economic resources and risk of divorce. Journal of Family Issues, 31, $1305-1323$

Thibaut, J., \& Kelley, H. (1959). The social psychology of groups. New York: Wiley.

Tichenor, V. J. (2005). Earning more and getting less: Why successful wives can't buy equality. New Brunswick: Rutgers University Press.

VanYperen, N., \& Buunk, B. (1991). Equity theory and exchange and communal orientation from a crossnational perspective. Journal of Social Psychology, 131(1), 5-20.

Voydanoff, P., \& Donnelly, B. (1999). The intersection of time in activities and perceived unfairness in relation to psychological distress and marital quality. Journal of Marriage and the Family, 61, 739-751.

Walster, E., Hatfield, E., Walster, G., \& Berscheid, E. (1978). Equity: Theory and research. Needham Heights, MA: Allyn \& Bacon.

Wang, Q. (2001). China's divorce trends in the transition toward a market economy. Journal of Divorce \& Remarriage, 35(1), 173-189. 
Wang, Q., \& Zhou, Q. (2010). China's divorce and remarriage rates: Trends and regional disparities. Journal of Divorce \& Remarriage, 51(4), 257-267.

West, C., \& Zimmerman, D. (1987). Doing gender. Gender and Society, 1, 125-151.

Whyte, M. (1990). Dating, mating, and marriage. New York: Aldine de Gruyter.

Wilcox, W., \& Nock, S. (2006). What's love got to do with it? Equality, equity, commitment and women's marital quality. Social Forces, 84(3), 1321-1345.

Wilkie, J., Ferree, M., \& Ratcliff, K. (1998). Gender and fairness: Marital satisfaction in two-earner couples. Journal of Marriage and the Family, 60, 577-594.

Winslow-Bowe, S. (2007). Relative income and marital conflict: The impact of fluctuating income advantages. Paper presented at Annual Meeting of American Sociological Association.

Winslow-Bowe, S. (2009). Spousal wage gap: Income disparities in couples. Retrieved August 28, 2009, from http://wfnetwork.bc.edu/encyclopedia_entry.php?id=16369\&area=All.

Yang, H.-C. (2004). The effects of gender role ideology, wife's employment, and perceived equity on marital quality: A case of young middle-class couples in Korea. Unpublished doctoral dissertation, The University of Connecticut, United States.

Zuo, J., \& Bian, Y. (2001). Gendered resources, division of housework, and perceived fairness: A case in urban China. Journal of Marriage and the Family, 63, 1122-1133.

Zuo, J., \& Bian, Y. (2005). Beyond resources and patriarchy: Marital construction of family decisionmaking power in post-Mao urban China. Journal of Comparative Family Studies, 36(4), 601.

Zuo, J., \& Jiang, Y. (2009). Urban women's work and family in social transition. Beijing: Contemporary China Publishing House. 